\title{
The Impact of National Formulary on Cough Medicine Prescrib- ing in Three Primary Health Care in Depok
}

\author{
Asma Zahidah, Nanda Asyura Rizkyani, Retnosari Andrajati \\ Faculty of Pharmacy, Universitas Indonesia, Gedung A Rumpun IImu Kesehatan Lantai 3, Kampus UI Depok, 16424, Jawa Barat, INDONESIA.
}

\begin{abstract}
Objective: To evaluate the use of cough medicine in Acute Respiratory Infections (ARI) patients in three primary health care in Depok in 2015 and suitability with the National Formulary. Method: The study design was descriptive analytic with retrospectively data collection from patient's prescription, Primary Health Care Management Information System (SIMPUS), and Medicine Management Information System (SIPO). Samples are taken from ARI's patients prescription from January until December 2015. The analysis was conducted on the prescription that meets the inclusion criteria quantitatively and qualitatively. Quantitative analysis is expressed in DDD and DDD/1000 patients/day. Results: The primary health care that has the biggest quantity of Medicines usage for DDD was in Cipayung (59136, 33g). Then, DDD/1000 patients/day for glyceryl guaiacolate, ambroxol, and dextromethorphan respectively was in Cipayung $(14.971 \mathrm{~g})$, Limo $(1.129 \mathrm{~g})$, and Limo $(0,0006 \mathrm{~g})$. The primary health care that most suitable with the National Formulary was Conclusion: In con-
\end{abstract}

clusion, all the cough medicine use in ARI patients in the three primary health care facilities in Depok in 2015 was unsuitable according to the National Formulary recommendations. Therefore, cough medicine use is needed to be evaluated further.

Key words: ATC/DDD, Cough, Cough medicine, Depok Primary Health Care, National Fomulary.

Correspondence :

Retnosari Andrajati

Faculty of Pharmacy, Universitas Indonesia, Gedung A Rumpun IImu Kesehatan Lantai 3, Kampus UI Depok, 16424, Jawa Barat, INDONESIA.

Phone no: (+6221) 7270031

Email: andrajati@farmasi.ui.ac.id

DOI: 10.5530/jyp.2017.1s.5

\section{INTRODUCTION}

A large amount of cough medicine is used by the people of Indonesia. Based on 2008 data from Depok's Public Health Service, the prevalence of patients registered in Depok's primary health care facilities who suffer from cough is $4 \% .^{1-3}$ This number does not include coughs caused by acute respiratory infections (ARIs). The prevalence of patients with ARI, based on the Diagnosis Health Professionals and Complaints of Residents, is $25.0 \%{ }^{4}$ To ensure the health of the Indonesian people, the Indonesian government implemented a national health insurance program. On the implementation of the program, health care facilities were asked to refer to the National Formulary when making decisions about prescribing medicines. ${ }^{1,3}$

The number of cough medicines for primary health care that are listed in the National Formulary is very limited. One medicine that is in the formulary is codeine $10 \mathrm{mg}$, to be used as an antitussive. ${ }^{4-6}$ The National Formulary has a limited inclusion of cough medicine because no evidence has been provided for the broad use of cough medicines. Nevertheless, cough medicine is prescribed in the health facilities. To determine the rational use of medicines in Indonesia, an evaluation can be done using the ATC/DDD classification. The ATC/DDD system classifies the use of medicine therapy to provide a tool to improve the quality of medicine use..$^{7-9}$ Previous studies on the use of cough medicine in Indonesia are limited. One study assessed the use of cough and cold medicines in paediatric patients under the age of 6 years. ${ }^{10-13}$ Therefore, additional research is needed to evaluate the patterns of medicine use in Indonesia using ATC/DDD.

The general objective of this study was to compare the use of cough medicine in ARI patients in three primary health care facilities in Depok in 2015 based on the classification of ATC/DDD. The specific objectives of this study are comparing the quantity and the quality of the use of cough medicine in ARI patients in three primary health care facilities in Depok in 2015 expressed in DDD units and DDD/1000 patients/day, which evaluate the suitability of the use of cough medicine in ARI patients in three primary health care facilities in Depok in 2015 with the National Formulary.

\section{METHODS}

The study design was cross-sectional using retrospective data from the Primary Health Care Management Information System (SIMPUS) and the Medicine Management Information System (SIPO). Data were taken from ARI patients' prescription information, which contained cough medicine that has DDD units, in Limo Primary Health Care, Cipayung Primary Health Care, and Bojongsari Primary Health Care, from January 1 through December 31, 2015. The prescription for ARI includes the following disease codes: J00 (acute nasopharyngitis), J01 (acute sinusitis), J02 (acute pharyngitis), J06 (acute upper respiratory tract infection), J18 (bronchopneumonia), and J22 (acute lower respiratory tract infection).

Cough medicine is classified by ATC classification and converted into DDD. The quantity of DDD in three primary health care facilities (Limo, Cipayung, and Bojongsari) was compared by DDD and DDD/1000 patients/day. Quality was compared by suitability of cough medicine with the National Formulary. This research was conducted from February to May 2016.

\section{RESULTS AND DISCUSSION}

Total prescriptions written were 124,427, with 22,631 prescriptions for patients with ARI. Of those, 11,481 prescriptions were for adults, and 
11,250 prescriptions were for children. The prescriptions that included cough medicine were 16,913 . The method of data collection is shown in Figure 1. The results of the study are reported as follows:

- Demographic and social information

- Medicine use information

- Quantity of medicine used

- Suitability of the medicine according to the National Formulary

\section{Demographic and social information}

The total number of patients in Cipayung, Limo, and Bojongsari was $13,667,7501$, and 4731 , respectively. The prevalence of male patients with ARIs was $43.29 \%$ in Cipayung, $45.72 \%$ in Limo, and $46.54 \%$ in Bojongsari. The prevalence of female patients with ARIs was $56.66 \%$ in Cipayung, $54.27 \%$ in Limo, and $53.46 \%$ in Bojongsari. As the data show, ARIs were more prevalent in females than in males. According to statistical data of Depok City in 2014, there were more males than females in the population. The prevalence of ARI patients in the age group 0-18 years was 55.17\% in Cipayung, 34.70\% in Limo, and 57.16\% in Bojongsari. The results showed a high prevalence of ARIs in the paediatric population. This could be a result of the immature immune system in children, causing them to be more easily infected.

Total prescriptions written for patients in the BPJS program in Cipayung, Limo, and Bojongsari was 19,193, 8697, and 14,130, respectively. Total prescriptions written for non-BPJS patients in Cipayung, Limo, and Bojongsari was $40,370,23,356$, and 18,680 , respectively The percentage of ARI patients' prescriptions covered by BPJS was $44.189 \%$ in Cipayung, $20.57 \%$ in Limo, and $42.9 \%$ in Bojongsari, and prescriptions not covered by BPJS was $55.82 \%$ in Cipayung, $79.43 \%$ in Limo, and $57.1 \%$ in Bojongsari. The percentage of patients with prescriptions for cough medicine covered by BPJS was $47.86 \%$ in Cipayung, $25.14 \%$ in Limo, and $46.5 \%$ in Bojongsari, and the percentage of cough medicines not covered by BPJS was 52.14\% in Cipayung, $74.86 \%$ in Limo, and 53.5\% in Bojongsari. The primary health care facility with the highest number of prescriptions is
Cipayung Primary Health Care, which provides health care 24 hours a day. Cipayung Primary Health Care has a higher number of patients than does Bojongsari and Limo. The analysis showed that there were more ARI patients who did not have BPJS status than ARI patients with BPJS status. There are still many patients who do not follow the BPJS program, because many people do not know about the program and the procedures for joining it.

\section{Medicine use information}

In the three primary health care facilities, the highest medicine use by prevalence were glyceryl guaiakolat, OBH, Ambroxol, and Ambroxol syrup. The results are provided in Table 1. The Limo, Cipayung, and Bojongsari primary health care facilities had the same numbers for prevalence. It is important to mention that dextromethorphan, either in the tablet or syrup form, is not always used in primary health care facilities in Indonesia, and is used little compared with other cough medicines. Dextromethorphan is a precursor group that is used for the pharmaceutical industry, non-pharmaceutical industries, and the development of science and technology. ${ }^{14}$

\section{Quantity of Medicine Use}

\section{Quantity of Medicine Use in DDD and DDD/1000 Patients/Day}

The primary health care facility that had the largest quantity of medicines for DDD use was in Cipayung $(59,136.33 \mathrm{~g})$, followed by Limo $(34,512.55 \mathrm{~g})$ and Bojongsari $(14,771.28 \mathrm{~g})$. The largest quantity of medicine use for DDD/1000 patients/day for glyceryl was Cipayung $(14,971 \mathrm{~g})$, which means that $1.497 \%$ of patients received prescriptions for glyceryl guaiakolat every day. The largest quantity of medicine use for DDD/1000 patients/day for ambroxol was Limo (1129 g), followed by Cipayung $(0,6398 \mathrm{~g})$ and Bojongsari $(0,4612 \mathrm{~g})$. The biggest quantity of medicines use for DDD/1000 patients/day for dextromethorphan was Limo $(0,0006 \mathrm{~g})$. The results are shown in Table 2.

\section{Table 1: Medicine use}

\begin{tabular}{|c|c|c|c|c|c|c|c|c|}
\hline \multirow{4}{*}{ No } & \multirow{4}{*}{ Medicine name } & \multirow{4}{*}{ Type } & \multicolumn{6}{|c|}{ Medicine Use in Primary Health Care } \\
\hline & & & \multicolumn{2}{|c|}{ Limo } & \multicolumn{2}{|c|}{ Cipayung } & \multicolumn{2}{|c|}{ Bojongsari } \\
\hline & & & \multirow{2}{*}{ BPJS } & Non & \multirow{2}{*}{ BPJS } & Non & \multirow{2}{*}{ BPJS } & Non \\
\hline & & & & BPJS & & BPJS & & BPJS \\
\hline 1 & Ambroxol & Tablet & 26400 & 78610 & 4341 & 4730 & 1124 & 1294 \\
\hline 2 & Ambroxol & Syrup & 125 & 374 & 33 & 38 & 8 & 11 \\
\hline 3 & Dextromethorphan & Tablet & 10 & - & - & - & - & - \\
\hline 4 & Dextromethorphan & Syrup & - & - & 1 & - & - & - \\
\hline 5 & $\mathrm{OBH}$ & Syrup & 177 & 662 & 775 & 844 & 82 & 89 \\
\hline 6 & Glyceryl guaiacolate & Tablet & 7045 & 20977 & 24427 & 26612 & 5896 & 6783 \\
\hline
\end{tabular}

Table 2. The quantity of medicine use in DDD and DDD / 1000 Patient / Day

\begin{tabular}{|c|c|c|c|c|c|c|c|c|c|c|}
\hline \multirow[t]{2}{*}{ No } & \multirow[t]{2}{*}{ Medicine Name } & \multirow[t]{2}{*}{ ATC } & \multicolumn{3}{|c|}{ DDD (g) } & \multirow[t]{2}{*}{$\begin{array}{c}\text { Total } \\
\text { DDD (g) }\end{array}$} & \multicolumn{3}{|c|}{$\begin{array}{l}\text { Quantity of Medicine Use in DDD } \\
\text { and DDD / } 1000 \text { Patient / Day (g) }\end{array}$} & \multirow[t]{2}{*}{$\begin{array}{c}\text { Total } \\
\text { DDD/1000pasien } \\
\text { hari }(\mathrm{g})\end{array}$} \\
\hline & & & Limo & Cipayung & Bojongsari & & Limo & Cipayung & Bojongsari & \\
\hline 1 & Glyceryl guaiacolate & R05CA03 & 31135 & 56710 & 14087.78 & 101932.78 & 10.417 & 14.971 & 9.497 & 34.885 \\
\hline 2 & Ambroxol & R05CB06 & 3375.88 & 2425 & 683.5 & 6474.38 & 1.129 & 0.6398 & 0.4612 & 2.1892 \\
\hline \multirow[t]{2}{*}{3} & Dextromethorphan & R05DA09 & 1.67 & 1.33 & - & 3 & 0.0006 & 0.0003 & - & 0.0009 \\
\hline & Total & & 34512.55 & 59136.33 & 14771.28 & 108410.16 & & & & \\
\hline
\end{tabular}


Table 3: Suitability of the medicine with the National Formulary

\begin{tabular}{cccccc}
\multirow{2}{*}{ No. } & \multirow{2}{*}{ Primary health care } & \multicolumn{2}{c}{$\begin{array}{c}\text { Suitability of the medicine with the } \\
\text { National Formulary (g) }\end{array}$} & \multicolumn{2}{c}{ Percentage (\%) } \\
\cline { 3 - 6 } & & Suitable & Unsuitable & Suitable & Unsuitable \\
\hline 1 & Limo & - & 34512.55 & - & 100 \\
2 & Cipayung & - & 9136.33 & - & 100 \\
3 & Bojongsari & - & 14771.28 & - & 100 \\
& Total & - & 108410.16 & - & 100 \\
\hline
\end{tabular}

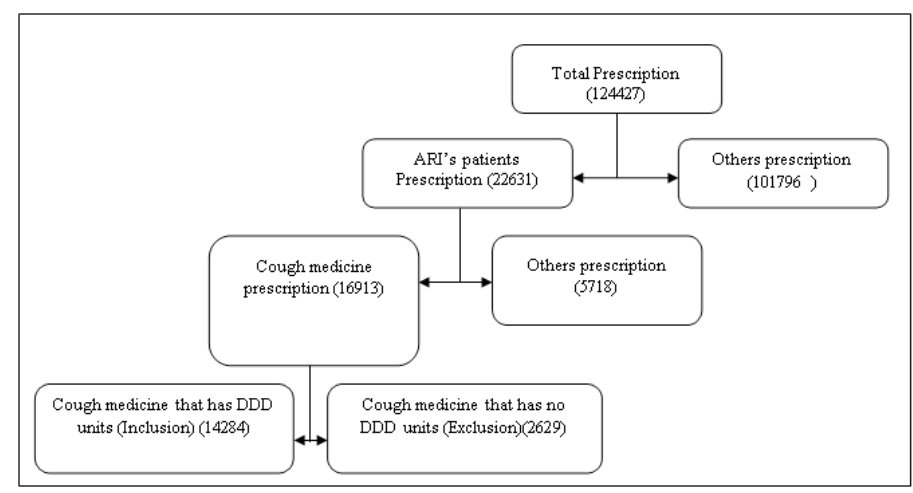

Figure 1: Data Collection.

\section{Suitability of the Medicine with the National Formulary}

The amount of medicine found to be unsuitable according to the $\mathrm{Na}$ tional Formulary was 34,512.55 $\mathrm{g}$ in Limo, 14,771.28 $\mathrm{g}$ in Bojongsari, and $9136.33 \mathrm{~g}$ in Cipayung. The results are shown in Table 3. The results show that cough medicines are still needed to reduce symptoms despite having no evidential basis. It would be better if the medicine provision in the National Formulary was changed in consideration of the actual situation occurring in the health care facilities. The procurement of medicines in the primary health care facilities is done using e-purchasing and e-catalogues. The use of medicines in the primary health care facilities should be adapted to the standard treatment and in accordance with applicable regulations. If patients need a medicine that is not listed in the National Formulary, then it can be granted if in accordance with the medical indications and the standards of medical services whose cost is included in capitation; the cost should not be passed on to participants. ${ }^{15}$

\section{CONCLUSION}

In conclusion, all the cough medicine use in ARI patients in the three primary health care facilities in Depok in 2015 was unsuitable according to the National Formulary recommendations. Therefore, cough medicine use is needed to be evaluated further.

\section{CONFLICT OF INTEREST}

There is no conflict of interest.

\section{REFERENCES}

1. Institution of Social and Health Insurence. The Rules of Institution of Social and Health Insurence Peraturan Number 1 Years 2014 about Health Insurence. Jakarta: Institution of Social and Health Insurence; 2014.

2. Agency Research and Development of Health. Basic of Health Research. Jakarta: Ministry of Health of the Republic of Indonesia; 2013.

3. Depok's Public Health Service. Profil Kesehatan Kota Depok. Depok: Depok's Public Health Service; 2008.

4. Minister of Health of The Republic of Indonesia. SK No. 328/Menkes/SK/ VIII/2013 about National Formulary. Jakarta: Menteri Kesehatan Republik Indonesia; 2013

5. Minister of Health of The Republic of Indonesia. SK No. 159/Menkes/SKN/2014 about National Formulary. Jakarta: Menteri Kesehatan Republik Indonesia; 2013.

6. WHO. Prevention and Controlling of ARI.. Jenewa: WHO.; 2007.

7. WHO. Guideline for ATC Classification and DDD Assignment. Oslo, Norwegia: WHO Collaborating Centre for Medicine Statistics Methodology; 2016

8. WHO. Introduction Medicine Utilization Research. Oslo: WHO; 2003.

9. Suman RK, Mohanty IR, Deshmukh YA. The concepts of drug utilization study. World Journal of Pharmaceutical and science. 2014; $3: 352-363$.

10. Corwin EJ. Handbook of Pathophysiology 3th Edition. USA: Lippincott Williams \&Wilkins; 2008.

11. Dipiro JT, et al. Pharmacotherapy. United States: The Mc-Graw-Hill Companies; 2008.

12. Soepardi S, Yulianto, Wardhana. Profil Penggunaan Obat Batuk Pilek pada Pasien Anak di Bawah Umur 6 tahun. Sari Pediatri. 2013; 14 (6).

13. Smith SM, Schroeder K, Fahey T. OTC Medictions for Acute Cough in Children and Adults in Ambulatory Setting.The Cochrane Collaboration: Wiley; 2012.

14. President of The Republic of Indonesia. Rules of President RI Nomor 44 Year 2010 about Precursor. Jakarta. 2010.

15. Minister of Health of The Republic of Indonesia. PMK 28 Year 2014 About Guidance of Social and Health Insurance. 2014

Article History: Submission Date : 16-01-2017; Revised Date : 28-01-2017; Accepted Date: 03-02-2017.

Cite this article: Zahidah A, Rizkyani NA, Andrajati R. The Impact of National Formulary on Cough Medicine Prescribing in Three Primary Health Care in Depok. J Young Pharm. 2017;9(1)Suppl:s16-s8. 